\title{
Comments on the manuscript "Hepatorenal syndrome: an update"
}

I read the article "Hepatorenal syndrome: an update" in São Paulo Med J with great interest. When I published a small study in 1996 with favorable results from the use of relatively small doses of BQ123 in severely affected patients, I tried unsuccessfully to attract commercial interest to pursue the investigation. The physiological effects of ET-1 in healthy volunteers in Rabelink's study ${ }^{2}$ seemed to affect them similarly to features seen in early hepatorenal syndrome (HRS) at comparable plasma levels, irrespective of the important question of intrarenal generation. Such effects in healthy subjects were completely abolished by selective ET-A blockade ${ }^{3}$. The use of combined ET-A and B antagonists has resulted in hypotension, but no other additional renal haemodynamic effects. ${ }^{4}$.
I have recently become aware of the paper by Moore et al. reporting a lack of benefit from a combined ET blocker in HRS, ${ }^{5}$ and interestingly also reporting hypotension, but as yet selective ET-A blockade does not seem to have been reattempted therapeutically. Is the author aware of any such investigation in process?

\section{AUTHOR INFRRMATION}

Charles Soper, MB MRCP. Nephrologist/Internist, Mayday University Hospital London Road, Thornton Heath, Croydon CR7 7YE, United Kingdom.

\section{Address for correspondence:}

At the author's request, no e-mail address or telephone numbers have

been published.

Copyright (C) 2008, Associação Paulista de Medicina

REFERENCES

1. Genzini T, Torricelli FC. Hepatorenal syndrome: an update. Sao Paulo Med J. 2007;125(1):50-6.

2. Rabelink TJ, Kaasjager KA, Boer P, Stroes EG, Braam B, Koomans HA. Effects of endothelin-1 on renal function in humans: implications for physiology and pathophysiology. Kidney Int. 1994;46(2):376-81.

3. Honing ML, Hijmering ML, Ballard DE, et al. Selective ET(A) receptor antagonism with ABT-627 attenuates all renal effects of endothelin in humans. J Am Soc Nephrol. 2000;11(8):1498-504

4. Goddard J, Johnston NR, Hand MF, et al. Endothelin-A receptor antagonism reduces blood pressure and increases renal blood flow in hypertensive patients with chronic renal failure: a comparison of selective and combined endothelin receptor blockade. Circulation. 2004;109(9):1186-93.
5. Wong F, Moore K, Dingemanse J, Jalan R. Lack of renal improvement with nonselective endothelin antagonism with tezosentan in type 2 hepatorenal syndrome. Hepatology. 2008; $47(1): 160-8$

Date of first submission: July 10, 2007

Last received: January 16, 2008

Accepted: January 17, 2008
Thank you for your comments.

Unfortunately, we have no clinical experience with endothelin antagonists. However, we have been treating many patients with hepatorenal syndrome (HRS) and we are very interested in any kind of better alternatives for them than albumin plus terlipressin, transjugular intrahepatic portosystemic shunt (TIPS) and others, while waiting for liver transplantation.

\section{AUTHDR INFDRMATIDN}

Tércio Genzini, MD. Staff surgeon in HEPATO Group, Hospital Beneficência Portuguesa, São Paulo, Brazil.

\section{Address for correspondence:}

Tércio Genzini

Rua Maestro Cardim, 354 - Conjunto 33 - Paraíso

São Paulo (SP) - Brasil - CEP 01323-000

Tel. (+55 11) 3289-5548

E-mail: t.genzini@hepato.com.br

Copyright @ 2008, Associação Paulista de Medicina 